\title{
INFLUENCE OF IRRIGATION INTERVALS AND ANTITRANSPIRANTS ON GROWTH, YIELD AND QUALITY OF STRAWBERRY UNDER DRIP IRRIGATION SYSTEM A -VEGETATIVE GROWTH, FRUIT QUALITY, EARLY AND TOTAL YIELD
}

\author{
Shadia A. Ismail and M. M. Mubarak \\ (1) Potato and Vegetatively Propagated Vegetable Crops Dept. Res. Hort. Res. Inst. ARC, Giza, \\ Egypt \\ (2) Soil science Dep., Fac. of Agric ., Ain Shams Uni., Cairo Egypt
}

Received: May 28, 2016

Accepted : Jun. 26,2016

\begin{abstract}
This study was carried out at El-Kanater Horticulture Research Station ,ElKaluobia Governorate during two successive seasons to illustrate the effect of three irrigation intervals (each 2,3, and 4 days) and five antitranspirants (potassium, sodium, and aluminum silicate ,magnesium carbonate and calcium carbonate) as well as control on growth, yield and its components of Festival strawberry cultivar. The experimental design was split plot design with three replications under drip irrigation system and clay soil. Results show clearly that plants irrigated each two or three days and spraying with one of the potassium silicate (kaolin) or magnesium carbonate or calcium carbonate as antitranspirants which gave the highest values of vegetative growth parameters compared to the control plants. However, irrigation each four days resulted in an increase in total soluble solids and fruit firmness with using calcium carbonate or kaolin. Irrigation intervals two or three days had no significant differences on early yield. The earliest yield/plant was obtained from irrigation each three days and foliar spraying of kaolin or magnesium carbonate or potassium silicate or calcium carbonate and sodium silicate in the two tested seasons, respectively. Total yield was adversely impact of irrigation spacing intervals. However, non significant differences were found between the irrigation each two and three days with using each of antitranspirants in total yield compared to untreated plants. The study recommend irrigation strawberry plants each three days with foliar spray of each kaolin or magnesium carbonate or calcium carbonate or potassium silicate and sodium silicate respectively, to increase the vegetative growth, fruit quality, early and total yield under drip irrigation system at Kalubia Governorate region .
\end{abstract}

Key wards: Strawberry, irrigation intervals antitranspirants, growth and yield.

\section{INTRODUCTION}

Strawberry plant (Fragaria $x$ ananasa Duch.) is one of the most important crops cultivated in the world and Egypt. Drought has a major impact on plant growth, development and limiting crop production especially strawberry plants because strawberry plants are sensitive to drought stress (Gerhmann,1985). Most of water absorbed by plants is lost through transpiration, reducing plant transpiration could conserve irrigation water and minimize plant stress. Many new methods to enhance plant tolerance to drought stress, such as application of antitranspirants. Klar, et.al., (1990) subjected strawberry plants to drought treatments during three growth phases. Water stress during vegetative growth had no significant effect on fruit production; however, stress during the flowering and fruit formation had an adverse effect on yield and fruit water content but had no effect on vitamin C contents. Mannini, and Gallina, (1994) reported that marketable yield and fruit weight were increased as irrigation rate increased. Fruit 
firmness, and titratable acidity decreased as irrigation rate increased when strawberry cultivars irrigated to replace 15,40 or $65 \%$ of evapotranspiration .

Foliar application of potassium silicate increased chlorophyll content and growth. potassium silicate also induced metabolic changes such as increased citric acid and malic acid levels, and decreased fructose, glucose, and sucrose contents. and elevated amounts of membrane lipids (Wang and Galletta1998) .Liu et al., (2001) found that there was a negative correlation with soil moisture and physical fruit properties(fruit hardness, soluble solid content, titratable acidity, sugar acid ratio and content of ascorbic acid) as well as positive correlation with plant height, number of leaves, fruit weight and yield of strawberry plants. Jifon and Syvertsen (2003) indicated that kaolin clay application on grapefruit trees decreased leaf temperature by $3^{\circ} \mathrm{C}$, as well as leaf to air vapor pressure, and improved net carbon dioxide assimilation and yield Kaolin application appear to have the ability to reduce the effect of water and / or heat stress and possibly to enhance canopy photosynthesis . (Rosati, (2007).

Klamkowski and Treder (2008) observed that drought stress diminished leaf area in all strawberry varieties. Bordonaba andTerry, (2009). noted that water-deficit affected both fruit physiology and biochemistry of strawberry cultivars where dry matter was increased, the concentration of sugars and some acids were generally higher in water-deficit derived fruit than from plants kept near field capacity. Ezzat et. al., (2009) reported using kaolin as antitranspirants on potato plants increased leaf resistance to diffusion of water vapor and kaolin had significant effects on photosynthetic pigments compared with control treatment. However, antitranspirants did not affect dry weight accumulation in the leaves, stems, roots, total plant leaf area, or leaf dry weight percentage in sweet pepper. (Francisco__and Rubio 2009) Kaolin treatment increased lycopene fruit content of tomato by $16 \%$,but did not affect total soluble solids content, fruit dry matter, juice $\mathrm{pH}$, titratable acidity or fruit firmness. (Vito et. al.,2009).

Terry, et. al., (2009) mentioned that health-related compounds/parameters (viz. antioxidant capacity and total phenolics) were generally much greater in deficit water -treated fruit. Glucose and fructose concentrations were 1.2-fold higher in deficit water -treated as compared to non-drought treatment. Strawberry yield was diminished as an outcome of water deficit ( $\mathrm{Li}$ et al. 2010). Foliar application of kaolin clay may reduce leaf and crown temperatures by reflecting solar radiation and decrease evaporation around strawberry crowns and leaf transpiration, thus allowing faster formation of new leaves and roots (Bielinski et al., 2012) .In addition, new leaf of strawberry production, stomata conductance, and photosynthetic rate were significantly reduced under water deficit (Grant, et al 2012). Foliar application of kaolin clay with the application of $70 \%$ of the sprinkler irrigation volume traditionally used by strawberry growers could save a significant water volume $(30 \%)$ while achieving the same plant establishment, early and total yield ( Santos, et. al., 2012 ). The mild and severe water stress treatments at fruiting stage or severe stress at flowering showed significantly lower fruit weights while fruit firmness was significantly increased by mild and severe stress. The total soluble solids (TSS) were not significantly affected by the water stress treatments (Modise, 2013 ). Application of calcium by spraying method had positive effects on growth of the plant because this element was inactive in the plant (Motamedi, 2013). Foliar spraying of antitranspirants increased the capacity of acclimation strawberry under drought 
Influence of irrigation intervals and antitranspirants on growth, $\ldots \ldots \ldots \ldots \ldots \ldots . . . . .$.

conditions, enhanced most of the growth parameters and a significant increase of root/shoot ratio, due to results in enhancement of root depth, providing greater water uptake, which is crucial for plant survival during drought conditions (Caulet et al., 2014). The effect of deficit irrigation on the strawberries plants, were determined also by( Arash et al. (2015), Deaquiz, et al. (2014) and Johnson and Simpson, (2014) they found that a mild stress had no effect on the flower numbers but the severe stress caused a reduction in yield. The effect of irrigation intervals on the quality of strawberry fruit was investigated recently by Akhtar, and Rab, (2015) they found the maximum fresh fruit weight, moisture content and ascorbic acid content were recorded with 4 days irrigation interval Such features declined with increasing irrigation intervals. By contrast, total sugars and titratable acidity were highest with 8 days irrigation interval and the highest total soluble solids was recorded with 10 days irrigation interval. From the results obtained by Arash et .al., (2015) on strawberry plants, drought stress had negative effects on leaf area, leaf number, and chlorophyll content. Foliar spray of magnesium carbonate as antitranspirants improved plant growth of taro as plant height, leaf number and leaf area, chlorophyll, yield, and its component, (El-Zohiri and El-sayed et.al., 2015). Three antitranspirants, were unable to mitigate drought stress in artichoke (Shinohara and Leskovar, 2014). The use of kaolin ,as antitranspirants, on olive trees increased chlorophyll content, (Khaleghi et al., 2015). Researches on the use of antitranspirants is quite limited on strawberry, therefore, this study was designed to investigate the effect of irrigation intervals and foliar spraying of some antitranspirants on some vegetative growth, fruit chemical and physical characteristics, early and total yield of Festival strawberry cultivar.

\section{MATERIALS AND METHODS}

Two experiments were conducted at Elkanter Research Station, Qaluobia Governorate during the two growing seasons of 2013 / 2014 and 2014 /2015 The soil was clay in texture. .Festival" strawberry cultivar was used in this study. Dates of planting were September $25^{\text {th }}$ and October $2^{\text {nd }}$ in 2013 and 2014 for the first and second seasons, respectively. All agricultural practices for cultivation were performed as recommended by Ministry of Agriculture and Land Reclamation. The treatments comprised three irrigation intervals (two days common used at the farm,three days and four days intervals) and six treatments of: tap water as control, potassium silicate $\left(\mathrm{k}_{2} \mathrm{O}_{3} \mathrm{Si}\right)$, sodium silicate $\left(\mathrm{Na}_{2} \mathrm{O}_{3} \mathrm{Si}\right)$ calcium carbonate $\left(\mathrm{CaCO}_{3}\right)$ magnesium carbonate $\left(\mathrm{MgCO}_{3}\right)$ and aluminum silicate $\left(\mathrm{Al}_{2} \mathrm{Si}_{2} \mathrm{O}_{7}\right)$ (kaolin), the concentration was 2\% used for all the treatments to improve water efficiency and reduce water requirements under drip irrigation system.

The foliar spray treatments were started after 45 days from transplanting and every 15 days until the end of May. The experiment was designed in a split plot arrangement with three replications. Irrigation intervals were in the main plots and antitranspirants used to minimize water requirements were allocated in the sub plots. At planting dates the fresh transplants were dipped in Rhizolex solution at rate of $2.0 \mathrm{~g} / \mathrm{l}$ for 20 minutes as recommended before transplanting .Plants were arranged in four rows-bed system with $120 \mathrm{~cm}$ width and 30 $\mathrm{cm}$ height .Plant distances were $25 \mathrm{~cm}$ apart (16 plants $/ \mathrm{m}^{2}$ ) Plot area was $34 \mathrm{~m}^{2}$. Three beds each with $20 \mathrm{~m}$ length and $1.7 \mathrm{~m}$ width. The drip irrigation was used in this study.

Data recorded : Five plants were taken from each experimental plot on March 15 to determine : Plant length $(\mathrm{cm})$, number of leaves, total leaf area /plant $\left(\mathrm{cm}^{2}\right)$, calculated as relation between unit area and 
leaf fresh weight using the following equation ,foliage dry weight \%, root length , root length ,crown diameter ,total chlorophyll content using SPAD Meter, fruit firmness ( $\mathrm{g} / \mathrm{cm} 2)$ determined by using a Shaltillon spectrometer (N.A., USA ) with a needle $1 \mathrm{~mm}$ in diameter early and total yield/plant and per Fadden were determined.

Leaf area $\left(\mathrm{cm}^{2}\right)=$

Disk area $\mathrm{x}$ No.Disks $\mathrm{x}$ Leaf Fresh Weight

Disk F.W.

Chemical characteristics of fruit i.e., total soluble solid content (TSS) determined using the hand refractometer. Samples of $100 \mathrm{~g}$ fruits from each experimental plot were used to determine the total acidity of juice by titration with $0.1 \mathrm{NaOH}$ solution using phenol phethalein indicator, according to the method described in A.O.A.C.(2000). Ascorbic acid content (mg/100 g) was determined by using 2,6 dichloro-Phenol indophenols for titration as the method mentioned in A.O.A.C.(2000).

\section{Statistical analysis:}

Data were subjected to statistical analyzed as split plot design according to the procedure described by Snedecor and Cochran (1982). Comparison among means of treatments were tested using Duncan multiple range test.

\section{RESULTS AND DISCUSSION 1-Number of leaves.}

Data tabulated in Table (1) indicate that the highest number of leaves were produced under irrigation every two and three days irrigation intervals. On the other hand, the lowest value of number of leaves was obtained under water stress (four days interval) in both seasons. These results are in agreement with Klamkowski and Treder (2008), Grant, et al. (2012), Arash et al. (2015) and El- sayed et.al, (2015) on strawberry.

It is evident from the results in Table (1) that the antitranspirants affected the number of leaves /plant, In the first season, foliar application of calcium carbonate or aluminum silicate produced the highest number of leaves. In addition, the highest values in the second. season were obtained from magnesium carbonate and kaolin treatments without significant differences among them and calcium carbonate or sodium silicate. While, the lowest values were detected from potassium silicate and untreated plants respectively.

Concerning the interactions between irrigation intervals and reducing water requirements treatments data in Table (1) showed that the best combination was detected with spraying of sodium silicate when plants irrigated every two days followed by most of antitranspirants under three days interval with non significant differences among them and calcium carbonate, magnesium carbonate and kaolin in the first season. However, kaolin produced the highest value of number of leaves /plant in the second season under the three days irrigation interval. Similar results were reported by using kaolin clay thus allowing faster formation of new leaves of strawberry plants Bielinski et al. ,(2012) mentioned that foliar application of kaolin clay may have reduced leaf and crown temperatures by reflecting solar radiation. Second, the product might have decreased evaporation around strawberry crowns and leaf transpiration,. While under four days irrigation interval with spraying of potassium or sodium silicate and untreated plants, produced the lowest values of leaves number respectively .Also these findings agree with those of El-Zohiri (2014) on taro and El-sayed, et.al., (2015) on strawberry.

\section{2- Leaf area .}

Data presented in Table (1) showed that leaves area of strawberry plants were significantly influenced by irrigation intervals, in the first season the highest water amount 
(two days irrigation interval) came in the first rank followed by the three days irrigation interval. On the other hand, the lowest leaves area were detected by four days irrigation interval . In this respect, the growth of plant is usually reduced under the condition of water stress, These results are in harmony with those reported by Deaquiz et al., (2014) and Arash et al., (2015) on strawberry .

Regarding to antitranspirants application effect, results in Table (1) indicate that all antitranspirants had significant effect on leaf area .The best treatments were detected with spraying of potassium silicate and aluminum silicate in the first season with no significant differences among them and calcium carbonate, In addition, potassium silicate gave the highest value of leaf area with no significant differences between it and kaolin in the second season.On the other hand, untreated plants recorded the lowest value of leaves area in both tested seasons.Our results are in agreement with the finding of Klamkowski and Treder.(2008) on strawberry cultivars, Abd El-Aal (2015) and Arash et al. (2015) on strawberry.

Table (1): Effect of Irrigation intervals, some antitranspirants and their interactions on Number of leaves and leaf area / plant during the two growing seasons of 2013/2014 and 2014/2015.

\begin{tabular}{|c|c|c|c|c|c|c|c|c|}
\hline \multirow{3}{*}{$\begin{array}{l}\text { Character } \\
\text { Treatments }\end{array}$} & \multicolumn{4}{|c|}{ No. of leaves/plant } & \multicolumn{4}{|c|}{ Leaf area $\left(\mathrm{cm}^{2}\right)$} \\
\hline & \multicolumn{8}{|c|}{ Irrigation intervals } \\
\hline & $I_{1}$ & $\mathrm{I}_{2}$ & $\mathrm{I}_{3}$ & Mean & $I_{1}$ & $\mathrm{I}_{2}$ & $I_{3}$ & Mean \\
\hline \multicolumn{9}{|c|}{ 2013-2014 } \\
\hline Control & 17.67 ef & $15.67 \mathrm{f}$ & $13.33 \mathrm{~g}$ & $15.56 \mathrm{C}$ & 457.5 ef & $290.8 \mathrm{~g}$ & $213.9 \mathrm{~h}$ & $320.7 \mathrm{C}$ \\
\hline P.S. & $18.67 \mathrm{de}$ & $22.33 \mathrm{bc}$ & $18.67 \mathrm{de}$ & $19.56 \mathrm{~B}$ & $567.5 \mathrm{ab}$ & $566.6 \mathrm{ab}$ & $438.8 \mathrm{f}$ & $524.3 \mathrm{~A}$ \\
\hline S.S. & $26.33 \mathrm{a}$ & $20.33 \mathrm{~cd}$ & $18.67 \mathrm{de}$ & $20.33 \mathrm{~B}$ & $532.9 \mathrm{bc}$ & 499.4 cde & 478.2 def & $503.5 \mathrm{~B}$ \\
\hline C.C. & $23.67 \mathrm{~b}$ & $20.67 \mathrm{~cd}$ & $20.33 \mathrm{~cd}$ & $21.56 \mathrm{~A}$ & $550.4 \mathrm{ab}$ & $495.6 \mathrm{cde}$ & 460.9 ef & 518.6AB \\
\hline M.C. & $20.33 \mathrm{~cd}$ & $20.33 \mathrm{~cd}$ & $20.33 \mathrm{~cd}$ & $19.86 \mathrm{~B}$ & $589.2 \mathrm{a}$ & $521.3 b c d$ & $445.4 \mathrm{f}$ & $502.3 \mathrm{~B}$ \\
\hline A.S. & $19.00 \mathrm{de}$ & 20.00 cde & $19.67 \mathrm{de}$ & $21.78 \mathrm{~A}$ & $569.4 \mathrm{ab}$ & $570.4 a b$ & $435.9 f$ & $525.2 \mathrm{~A}$ \\
\hline Mean & $20.95 \mathrm{~A}$ & $19.89 \mathrm{AB}$ & $18.5 \mathrm{~B}$ & & $544.5 \mathrm{~A}$ & 490.7B & $412.2 \mathrm{C}$ & \\
\hline \multicolumn{9}{|c|}{$2014-2015$} \\
\hline Control & $16.33 \mathrm{~h}$ & $12.67 \mathrm{i}$ & $11.67 i$ & $13.56 \mathrm{C}$ & $511.6 \mathrm{bcd}$ & $241.3 \mathrm{~g}$ & $197.8 \mathrm{~g}$ & $316.9 \mathrm{C}$ \\
\hline P.S. & 19.33cdef & 19.33cdef & $18.67 \mathrm{fgh}$ & $19.11 \mathrm{~B}$ & $569.1 \mathrm{ab}$ & $546.1 \mathrm{abc}$ & $417.4 \mathrm{f}$ & $510.9 \mathrm{~A}$ \\
\hline S.S. & $22.00 \mathrm{ab}$ & 20.00 cde & $16.67 \mathrm{gh}$ & $19.56 \mathrm{AB}$ & $547.1 \mathrm{abc}$ & 467.1 def & 436.6 ef & $483.6 \mathrm{~B}$ \\
\hline C.C. & 20.00 cde & 19.67cdef & $18.00 \mathrm{def}$ & $19.22 \mathrm{AB}$ & $538.3 \mathrm{abc}$ & 459.5 def & 443.9 ef & $480.5 \mathrm{~B}$ \\
\hline M.C. & $21.00 \mathrm{abc}$ & $20.67 \mathrm{abc}$ & 19.33cdef & $20.33 \mathrm{~A}$ & $581.5 \mathrm{a}$ & $469.5 \mathrm{def}$ & 430.7 ef & $493.9 \mathrm{AB}$ \\
\hline A.S. & $18.33 a b$ & $22.33 \mathrm{a}$ & $20.33 \mathrm{bcd}$ & $20.33 \mathrm{~A}$ & 564.1ab & $490.8 \mathrm{cde}$ & $414.0 \mathrm{f}$ & 489.6 AB \\
\hline$\overline{M \epsilon}$ & $19.50 \mathrm{~A}$ & $19.11 \mathrm{~A}$ & $17.45 \mathrm{~B}$ & & $552 . .0 \mathrm{~A}$ & $45.7 \mathrm{~B}$ & $390.1 \mathrm{~B}$ & \\
\hline
\end{tabular}

$\mathrm{I}_{1}$-Two days interval $\mathrm{I}_{2}$ - three days interval $\mathrm{I}_{3}$ - four days interval

Control P.S.- Potassium silicate S.S.- Sodium silicate C.C.- Calcium carbonate M.C.--Magnesium carbonate A.S - aluminum silicate (Kaolin)Values within the column or rows followed by the same capital or small letter /s do not significantly differ from each other according to Duncan 's multiple range test at 5 $\%$ level 
Concerning the interaction effect, data listed in Table (1) clearly indicate that magnesium carbonate had the highest value of leaf area under two days irrigation intervals in both tested seasons. In addition, no significant differences among them and calcium carbonate, potassium silicate and kaolin under two or three days irrigation interval in the two tested season were found. Also, all treatments of antitranspirants under the water stress had significant increment in leaves area as compared to the control. These results are not in agreement with Caulet et. al., (2014).

\section{3-Plant length}

It's obvious from Table (2) that the highest values of plant length were observed by irrigation of plants every two days. While the lowest values were achieved with three and four days irrigation intervals in the first season. Also, in the second season, there is no significant differences were detected between two and three days irrigation intervals. Stress water condition caused of producing the least plant height in the second season as found by Ezzat et. al., (2009). As for the effect antitranspirants substances, results in Table (2) indicated that foliar spraying of calcium carbonate recorded the highest values of plant length in the two tested seasons. Also, there were no significant differences between calcium carbonate, magnesium carbonate and kaolin were detected in the both seasons. However the lowest value was resulted from the control without significant differences between it and each of potassium and sodium silicate.in both seasons.Obtained results are agreeable with those reported by Ezzat et .al., (2009) using kaolin on potato and (Gawish and Fattahalla 1997 , ElZohiri,2014) using calcium carbonate on taro and El-sayed, (2015)on strawberry .Data presented in Table (2) showed the best combination was resulted from two days irrigation interval with spraying of magnesium carbonate in the first season plus calcium carbonate and kaolin in the second season .Moreover, the same antitranspirants treatments under three and four days irrigation intervals had the highest values of plant length compared to the control.

\section{4-Foliage dry matter \%.}

Data shown in Table (2) indicate that irrigation intervals were significantly affected on the foliage dry matter $\%$ and the highest values were observed under irrigation every two days. However, no significant differences were detected by two and three days intervals and the lowest value was obtained from the four days irrigation condition The current results are in harmony with those of Deaquiz, et .al., (2014) and Arash et .al., (2014) on strawberry.

According to antitranspirants, it 's obvious from data presented in Table (2) that the highest values of foliage dry matter were resulted from spraying of kaolin and calcium carbonate in the first season in addition to, magnesium carbonate in the second season. In general all antitranspirants treatments showed significant increment as compared to control. Such results are in the same line with those obtained by Ezzat et al., (2009) upon potato using kaolin and Zohiri and Abd El-Aal (2014) upon taro using magnesium carbonate Spraying kaolin significantly increased foliage dry weight \%. It could be suggested that foliar spray with kaolin led to reduce the transpiration rate, and this in turn led to keep higher water content in the plant tissues and hence might favor the plant metabolism, the physiological processes, photosynthetic rate, carbohydrate metabolism and many other important functions that directly affect plant growth Bafeel and Moftah, (2008) on eggplant. 
Concerning the interaction treatments, results in Table (2) revealed that irrigation every two days with spraying of potassium silicate, calcium carbonate and kaolin were recorded the highest values of foliage dry matter with no significant differences between them and the control in the first season only However, in the second season spraying with sodium silicate had the highest value of foliage dry matter.The differences were not significant between two and three days irrigation intervals with each of calcium carbonate, magnesium carbonate and kaolin in the two tested seasons. Moreover, foliar spraying with the previous materials with irrigation every four days had the same significant increment in the first season. In this respect supplementary calcium could ameliorate the negative effects of salinity on dry mass production ( Khayyat et al. , 2009) on strawberry. Also, our results in the same line with those obtained by Ezzat et .al., (2009) on potato plants.

Table (2): Effect of Irrigation water intervals, some antitranspirants and their Interactions on plant length and foliage dry weight \% during the two growing Seasons of 2013/2014 and 2014/2015.

\begin{tabular}{|c|c|c|c|c|c|c|c|c|}
\hline \multirow{3}{*}{ Character } & \multicolumn{4}{|c|}{$\begin{array}{c}\text { Plant length }(\mathrm{cm}) \\
2013 / 2014\end{array}$} & \multicolumn{4}{|c|}{$\begin{array}{l}\text { Foliage dry weight (\%) } \\
2013 / 2014\end{array}$} \\
\hline & \multicolumn{8}{|c|}{ Irrigation intervals } \\
\hline & $I_{1}$ & $\mathrm{I}_{2}$ & $\mathrm{I}_{3}$ & Mean & $\mathrm{I}_{1}$ & $\mathrm{I}_{2}$ & $\mathrm{I}_{3}$ & Mean \\
\hline \multicolumn{9}{|c|}{ 2013-2014 } \\
\hline Control & $18.40 \mathrm{bc}$ & $12.57 \mathrm{ij}$ & $11.07 \mathrm{~J}$ & $14.01 \mathrm{~B}$ & $33.19 a b c$ & $25.87 \mathrm{e}$ & $19.70 \mathrm{f}$ & $27.50 \mathrm{C}$ \\
\hline P.S. & $17.50 \mathrm{~cd}$ & $13.33 \mathrm{ghi}$ & $14.83 \mathrm{fgh}$ & $15.22 \mathrm{AB}$ & $36.95 \mathrm{a}$ & 29.74 cde & $27.07 \mathrm{e}$ & $31.00 \mathrm{BC}$ \\
\hline S.S. & $17.57 \mathrm{~cd}$ & 15.00 efg & $15.00 \mathrm{efg}$ & $15.86 \mathrm{AB}$ & $31.71 \mathrm{bdc}$ & $33.81 \mathrm{ab}$ & $28.44 \mathrm{de}$ & $33.32 \mathrm{~B}$ \\
\hline C.C. & $19.70 \mathrm{~b}$ & 15.67 ef & $13.50 \mathrm{ghi}$ & $16.36 \mathrm{~A}$ & $36.07 \mathrm{a}$ & $32.36 \mathrm{bc}$ & $31.72 \mathrm{bcd}$ & $35.05 \mathrm{AB}$ \\
\hline M.C. & $22.27 \mathrm{a}$ & 15.60 ef & $13.70 \mathrm{ghi}$ & $17.12 \mathrm{~A}$ & $35.53 \mathrm{ab}$ & $33.20 \mathrm{abc}$ & $33.87 \mathrm{ab}$ & $34.20 \mathrm{~B}$ \\
\hline A.S. & $19.83 b$ & $16.60 \mathrm{de}$ & $13.17 \mathrm{gh}$ & $16.53 \mathrm{~A}$ & $36.63 \mathrm{a}$ & $33.16 \mathrm{abc}$ & $33.85 \mathrm{ab}$ & $39.54 \mathrm{~A}$ \\
\hline Mean & $19.21 \mathrm{~A}$ & $14.79 \mathrm{~B}$ & $13.54 \mathrm{~B}$ & & $34.85 \mathrm{~A}$ & $31.35 \mathrm{AB}$ & $29.11 \mathrm{~B}$ & \\
\hline \multicolumn{9}{|c|}{$2014-2015$} \\
\hline Control & $18.17 \mathrm{bc}$ & $14.17 \mathrm{gh}$ & $10.73 \mathrm{i}$ & $14.63 \mathrm{C}$ & 32.52 defg & $24.33 \mathrm{j}$ & $21.36 \mathrm{k}$ & $26.44 \mathrm{C}$ \\
\hline P.S. & $16.77 \mathrm{de}$ & $18.17 \mathrm{bc}$ & $13.33 \mathrm{~h}$ & $16.09 \mathrm{BC}$ & $33.46 \mathrm{bcdef}$ & $28.31 \mathrm{hi}$ & $26.54 \mathrm{ij}$ & 29.44 B \\
\hline S.S. & $19.33 a b$ & $14.50 \mathrm{fgh}$ & $14.5 \mathrm{gh}$ & 16.11ABC & $35.97 \mathrm{a}$ & $31.41 \mathrm{fg}$ & $30.35 \mathrm{gh}$ & 32.57 B \\
\hline C.C. & $19.83 \mathrm{a}$ & $17.83 \mathrm{~cd}$ & $14.83 \mathrm{fg}$ & $17.49 \mathrm{~A}$ & $35.14 \mathrm{abc}$ & 34.11abcde & 32.93 czdef & $34.06 \mathrm{~A}$ \\
\hline M.C. & $20.17 \mathrm{a}$ & $16.50 \mathrm{e}$ & $14.17 \mathrm{fgh}$ & $16.95 \mathrm{AB}$ & $34.51 \mathrm{ab}$ & $35.28 \mathrm{abc}$ & 32.8 cdef & $35.53 \mathrm{~A}$ \\
\hline A.S. & $20.17 \mathrm{a}$ & 15.60 ef & $14.33 \mathrm{fgh}$ & $16.7 \mathrm{AB}$ & $34.8 \mathrm{abcd}$ & 32.08 efg & 34.04 abcde & $36.66 \mathrm{~A}$ \\
\hline Mean & $19.07 \mathrm{~A}$ & $16.13 \mathrm{AB}$ & $13.65 \mathrm{~B}$ & & $35.08 \mathrm{~A}$ & $30.99 \mathrm{AB}$ & $29.97 \mathrm{~B}$ & \\
\hline
\end{tabular}

$\mathrm{I}_{1}$-Two days interval $\mathrm{I}_{2}$ - three days interval $\mathrm{I}_{3}$ - four days interval

1- Control P.S.- Potassium silicate S.S.- Sodium silicate C.C.- Calcium carbonate M.C.--Magnesium carbonate

A.S - aluminum silicate (Kaolin)Values within the column or rows followed by the same capital or small letter /s do not significantly differ from each other according to Duncan 's multiple range test at $5 \%$ level 


\section{Number of roots}

Data in Table (3) show that there was a significant differences between the three irrigation intervals on the number of roots of strawberry plants in both tested seasons . As for the effect of antitranspirants application, obvious results from Table (3) reveal that the highest number of roots was produced from the plants that spraying with magnesium carbonate without significant differences with calcium carbonate and kaolin in the two seasons .In this respect, spray-treated plants rooted more quickly .Concerning the effect of interactions among the three irrigation intervals and foliar materials spray results indicate that under irrigation every two days with spraying of calcium carbonate or magnesium carbonate plants gave the highest number of roots in both seasons. Moreover, spraying each of calcium carbonate and kaolin under three days irrigation interval showed high significant differences compared to the other antitranspirants substances and untreated plants .In this respect, Bielinski et. al., (2012) mentioned that kaolin clay significantly increased new roots formation. Also, foliar spraying of magnesium carbonate under water stress conditions still better than the other antitranspirants materials and the untreated plants in the two tested seasons.

Table (3): Effect of Irrigation intervals, some antitranspirants and their interactions on number of roots and root length $(\mathrm{cm})$ during the two growing seasons of 2013/2014 and 2014/2015

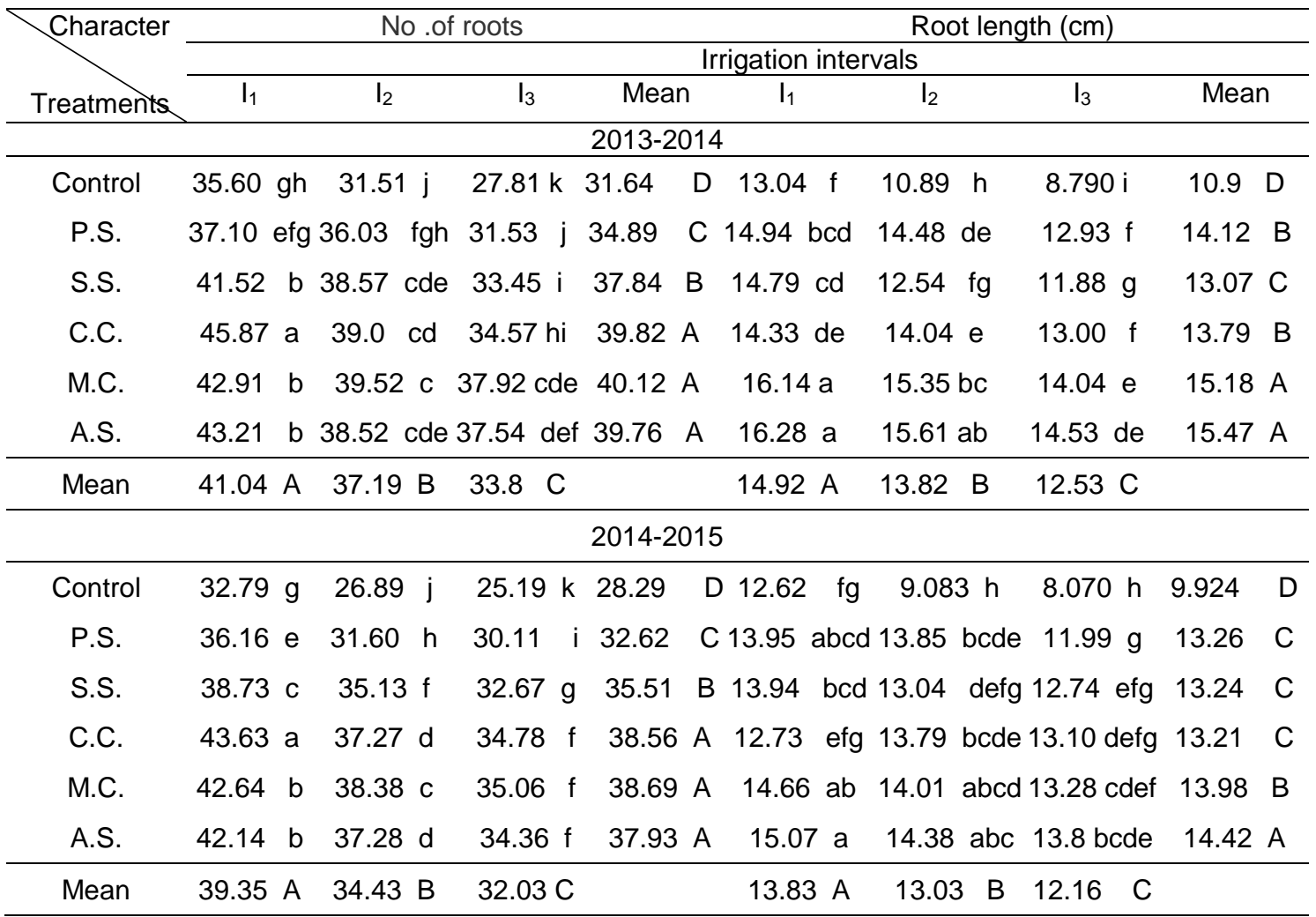

$\mathrm{I}_{1}$-Two days interval $\mathrm{I}_{2}$ - three days interval $\mathrm{I}_{3}$ - four days interval1- Control P.S.- Potassium silicate S.S.Sodium silicate- C.C.- Calcium carbonate M.C.--Magnesium carbonate A.S - aluminum silicate (Kaolin)Values within the column or rows followed by the same capital or small letter /s do not significantly differ from each other according to Duncan 's multiple range test at $5 \%$ level 


\section{5-Roots length}

Data tabulated in Table (3) show clearly there was a significant difference among the three irrigation intervals on roots length in the two tested season

In respect to the treatments of antitranspirants effect, spraying of magnesium carbonate or kaolin had the highest values of root length in the two studied seasons..All treatments had significant increments compared to the untreated plants. These results are in harmony with those reported by Caulet et. al., (2014).

As for the effect of the interaction, results in Table (3) indicate that two days irrigation interval and foliar spraying of magnesium carbonate or kaolin had the highest values of root length followed by the same treatment with irrigated plants each three days in the two studied seasons. However, under water stress and spraying any of antitranspirants, plants produced the shortest roots.

\section{6-Crown diameter}

In Table (4) data clearly indicate that irrigation intervals under study had significant effects on crown diameter of plant in the two tested seasons. Such results are in agreement with the findings of Liu et. al., (2001) and Klamkowski and Treder (2008) on strawberry. As for the antitranspirants effect results presented in Table (4) illustrate that foliar spraying of calcium carbonate produced the highest value of crown diameter with no significant differences among it and kaolin or potassium silicate in the first season. On the other hand, in the second season kaolin recorded the highest values of crown diameter with no significant differences between it and magnesium carbonate. However; the lowest values were detected from control. Data in Table (4) revealed that under all irrigation intervals and foliar spraying of calcium carbonate had the highest value of crown diameter in the first season followed by kaolin.While, in the second season kaolin reveled the highest values and all antitranspirants had a positive effect on crown diameter under irrigation each two or three days intervals compared to the control.

\section{7-Fruit firmness}

Data in Table (4) indicate that firmness of strawberry fruits were significantly influenced by the irrigation intervals and the highest value of firmness was obtained from the plants that irrigated each four days followed by that irrigated each three days While, the lowest value of firmness was detected by two days irrigation interval, These results are in harmony with those obtained by Modise,(2013) and Mannini, and Gallina(1994) on strawberry .Moreover, it is evident from the table that the foliar application of calcium carbonate and kaolin were superior antitranspirants that gave the highest value of fruit firmness followed by sodium silicate in the first season. While in the second season plants treated with calcium carbonate showed the highest values of fruit firmness followed by kaolin treatment compared to the control.

Regarding the interactions effect, data in Table (4) indicate that foliar application of calcium carbonate and kaolin under four days irrigation interval gave the highest values of fruit firmness followed by the three days irrigation interval. In this connection, application of the calcium by spraying method had positive effects on growth of the plant. and fruit firmness ( Motamedi, et. al. , 2013). 
Table (4): Effect of Irrigation intervals, some antitranspirants and their interactions on and fruit firmness crown diameter during the two growing seasons of 2013/2014 and 2014/2015

\begin{tabular}{|c|c|c|c|c|c|c|c|c|c|}
\hline \multirow{3}{*}{ Character } & \multicolumn{6}{|c|}{ Crown diameter(cm) } & \multicolumn{3}{|c|}{ Firmness $\left(\mathrm{g} / \mathrm{cm}^{2}\right)$} \\
\hline & \multicolumn{9}{|c|}{ Irrigation intervals } \\
\hline & $\mathrm{I}_{1}$ & $\mathrm{I}_{2}$ & $I_{3}$ & & Mean & $I_{1}$ & $\mathrm{I}_{2}$ & $I_{3}$ & Mean \\
\hline \multicolumn{10}{|c|}{$2013-2014$} \\
\hline Control & $1.612 \mathrm{bcd}$ & $0.9587 \mathrm{e}$ & 0.8033 & & $1.125 \mathrm{D}$ & $193.0 \mathrm{k}$ & $218.0 \mathrm{j}$ & $285.0 \mathrm{f}$ & $299.7 \mathrm{C}$ \\
\hline P.S. & $1.763 a b$ & $1.730 \mathrm{abc}$ & 1.543 & $d$ & $1.679 \mathrm{ABC}$ & 247.7 hil & $284.7 \mathrm{f}$ & $348.0 \mathrm{~cd}$ & $300.0 \mathrm{C}$ \\
\hline S.S. & $1.761 \mathrm{ab}$ & $1.650 \mathrm{abcd}$ & 1.517 & $d$ & $1.643 \mathrm{C}$ & $267.3 \mathrm{fgh}$ & $321.7 \mathrm{e}$ & $366.3 \mathrm{bc}$ & $331.4 \mathrm{~B}$ \\
\hline C.C. & $1.761 \mathrm{ab}$ & $1.742 a b$ & $1.659 \mathrm{ak}$ & $\mathrm{cd}$ & $1.721 \mathrm{~A}$ & $288.7 f$ & $383.0 \mathrm{~b}$ & $415.0 \mathrm{a}$ & $354.4 \mathrm{~A}$ \\
\hline M.C. & $1.734 a b$ & $1.724 a b c$ & 1.552 & $c d$ & $1.670 \mathrm{BC}$ & $259.7 \mathrm{gh}$ & $319.7 e$ & $348.0 \mathrm{~cd}$ & $312.1 \mathrm{C}$ \\
\hline A.S. & $1.813 \mathrm{a}$ & $1.743 a b$ & 1.554 & $\mathrm{~cd}$ & $1.703 \mathrm{AB}$ & $278.3 \mathrm{fg}$ & $359.7 \mathrm{c}$ & $415.0 \mathrm{a}$ & $357.4 \mathrm{~A}$ \\
\hline Mean & $1.741 \mathrm{~A}$ & $1.591 \mathrm{~B}$ & $1.438 \mathrm{C}$ & & & $253.8 \mathrm{C}$ & $300.0 \mathrm{~B}$ & $346.7 \mathrm{~A}$ & \\
\hline \multicolumn{10}{|c|}{$2014-2015$} \\
\hline Control & $1.615 a b$ & $0.8937 \quad c$ & 0.7537 & $\mathrm{C}$ & $1.087 \quad \mathrm{C}$ & $222.0 \mathrm{~g}$ & $211.7 \mathrm{~g}$ & $239.3 f$ & $214.3 \mathrm{E}$ \\
\hline P.S. & $1.685 \mathrm{ab}$ & $1.659 a b$ & 1.541 & b & $1.629 \mathrm{~B}$ & $251.7 f$ & $286.3 \mathrm{e}$ & $354.0 \mathrm{c}$ & 294.7 D \\
\hline S.S. & $1.718 \mathrm{ab}$ & $1.645 \mathrm{ab}$ & 1.571 & $b$ & $1.645 \mathrm{~B}$ & $252.0 \mathrm{f}$ & 275.7 e & $360.3 \mathrm{c}$ & $296.0 \mathrm{CD}$ \\
\hline C.C. & $1.688 \mathrm{ab}$ & $1.650 \mathrm{ab}$ & 1.563 & b & $1.634 \mathrm{~B}$ & $275.7 \mathrm{e}$ & $351.7 \mathrm{c}$ & $382.0 \mathrm{~b}$ & $351.1 \mathrm{~A}$ \\
\hline M.C. & $1.735 a b$ & $1.665 \mathrm{ab}$ & 1.597 & b & $1.666 \mathrm{AB}$ & $255.0 \mathrm{f}$ & $316.3 d$ & $357.3 \mathrm{c}$ & $306.6 \mathrm{C}$ \\
\hline A.S. & $1.810 \mathrm{a}$ & $1.692 a b$ & 1.607 & b & $1.703 \mathrm{~A}$ & $284.7 \mathrm{e}$ & $326.3 d$ & $417.0 \mathrm{a}$ & 328.0 B \\
\hline Mean & $1.709 \mathrm{~A}$ & $1.534 \mathrm{~B}$ & 1.439 & $B$ & & $251.8 \mathrm{C}$ & $294.2 \mathrm{~B}$ & $349.3 \mathrm{~A}$ & \\
\hline
\end{tabular}

$\mathrm{I}_{1}$-Two days interval $\mathrm{I}_{2}$ - three days interval $\mathrm{I}_{3}$ - four days interval

1- Control P.S.- Potassium silicate S.S.- Sodium silicate C.C.- Calcium carbonate M.C.--Magnesium carbonate

A.S- aluminum silicate (Kaolin)Values within the column or rows followed by the same capital or small letter /s do not significantly differ from each other according to Duncan 's multiple range test at $5 \%$ level

\section{8-Total soluble solids content (TSS) .}

Data in Table (5) indicate that fruits produced from plants irrigated every three or four days gave significant higher values of TSS compared with two days irrigation interval in the two tested seasons. Fruits produced under low water levels had higher TSS because of water deficit accumulated more sugars than those riped under the high water levels. These results agree with those of ( Akhtar and Rab (2015) and Terry, et al., (2009) ).
Results in Table (5) show also that fruits produced from the spraying of magnesium carbonate or kaolin followed by calcium carbonate gave significant higher values of TSS compared to the other antitranspirants treatments in the two tested seasons. These results are in harmony with Wang and Galletta, (1998) on strawberry

Results in Table (5) indicate that the highest values of T.S.S. were obtained from spraying magnesium carbonate or kaolin under irrigation each four days with non significant differences with application of calcium carbonate interval in the two tested seasons. 
Table (5): Effect of Irrigation intervals, some antitranspirants and their interactions on total soluble solids \% and acidity \% during the two growing seasons of 2013/2014 and 2014/2015

\begin{tabular}{|c|c|c|c|c|c|c|c|c|}
\hline \multirow{3}{*}{$\begin{array}{l}\text { Character } \\
\text { Treatments }\end{array}$} & \multicolumn{4}{|c|}{ T.S.S (\%) } & \multicolumn{4}{|c|}{ Acidity(\%) } \\
\hline & \multirow[b]{2}{*}{$\mathrm{I}_{1}$} & \multirow[b]{2}{*}{ I } & \multirow[b]{2}{*}{$\mathrm{I}_{3}$} & \multicolumn{3}{|c|}{ Irrigation intervals } & & \multirow[b]{2}{*}{ Mean } \\
\hline & & & & Mean & $\mathrm{I}_{1}$ & $\mathrm{I}_{2}$ & & \\
\hline \multicolumn{9}{|c|}{ 2013-2014 } \\
\hline Control & $9.233 \mathrm{gh}$ & $8.093 \mathrm{hi}$ & 9.043 ghi & $8.79 \mathrm{D}$ & $1.041 \mathrm{a}$ & $0.8507 \mathrm{bc}$ & 0.7217 defs & g $0.871 \mathrm{~A}$ \\
\hline P.S. & $9.567 \mathrm{fgh}$ & 10.57 efg & $9.633 \mathrm{fg}$ & $9.922 \mathrm{C}$ & 0.805 cde & $0.8407 \mathrm{~cd}$ & $0.6620 \mathrm{fgh}$ & i $0.769 \mathrm{~A}$ \\
\hline S.S. & $9.000 \mathrm{ghi}$ & 10.90 def & 10.57 efg 1 & $10.16 \mathrm{BC}$ & $1.020 \mathrm{a}$ & $1.004 \mathrm{a}$ & $0.6107 \mathrm{ghi}$ & i $0.878 \mathrm{~A}$ \\
\hline C.C. & $7.500 \mathrm{i}$ & 11.43 cde & $13.47 a b$ & $10.80 \mathrm{~B}$ & $1.072 \mathrm{a}$ & 0.7693 def & $0.5593 i$ & $0.800 \mathrm{~A}$ \\
\hline M.C. & $9.17 \mathrm{ghi}$ & $12.80 \mathrm{abc}$ & $13.50 \mathrm{ab}$ & $11.82 \mathrm{~A}$ & $1.066 \mathrm{a}$ & $0.6337 \mathrm{ghi}$ & $0.6477 \mathrm{fgh}$ & i $0.782 \mathrm{~A}$ \\
\hline A.S. & $9.833 \mathrm{fgh}$ & $12.23 \mathrm{bcd}$ & $13.90 \mathrm{a}$ & $11.99 \mathrm{~A} \quad 0$ & $0.9707 \mathrm{ab}$ & 0.6917 efgh & $0.5773 \mathrm{hi}$ & $0.747 \mathrm{~A}$ \\
\hline Mean & $9.033 \mathrm{~B}$ & $10.99 \mathrm{AB}$ & $11.00 \mathrm{AB}$ & & $0 . .996 \mathrm{~A}$ & $0.798 \mathrm{AB}$ & $0.629 \mathrm{~B}$ & \\
\hline \multicolumn{9}{|c|}{$2014-2015$} \\
\hline Control & 9.433 fghij & $8.000 \mathrm{k}$ & $8.790 \mathrm{ijk}$ & $8.741 \mathrm{C}$ & $1.311 \mathrm{a}$ & $0.8037 \mathrm{cde}$ & 0.7537 def & $0.956 \mathrm{~A}$ \\
\hline P.S. & 9.100 hijk & 10.50 defg & 10.10 efghi & i $9.900 \mathrm{~B}$ & $0.838 \mathrm{cde}$ & $0.8460 \mathrm{~cd}$ & $0.5987 \mathrm{~g}$ & $0.761 \mathrm{~B}$ \\
\hline S.S. & 9.167 ghijk & $10.70 \mathrm{def}$ & 10.23 defg & $10.03 \mathrm{~B}$ & $1.131 \mathrm{~b}$ & 0.7513 def & $0.5883 \mathrm{~g}$ & $0.824 \mathrm{AB}$ \\
\hline C.C. & 8.833 ijk & $11.07 \mathrm{cde}$ & $12.70 \mathrm{ab}$ & $10.87 \mathrm{AB}$ & $3 \quad 1.039 b$ & $0.7597 \mathrm{cdef}$ & $\mathrm{f} 0.5873 \mathrm{~g}$ & $0.795 \mathrm{AB}$ \\
\hline M.C. & 8.703 jk & $12.17 \mathrm{abc}$ & 12.70ab & $11.19 \mathrm{~A}$ & $1.054 \mathrm{~b}$ & $0.6513 \mathrm{fg}$ & $0.6030 \mathrm{~g}$ & $0.769 \mathrm{~B}$ \\
\hline A.S. & 9.900efghij & $11.57 \mathrm{bcd}$ & $13.40 \mathrm{a}$ & $11.62 \mathrm{~A}$ & $1.069 \mathrm{~b}$ & $0.8747 \mathrm{c}$ & 0.7240 ef & $0.889 \mathrm{AB}$ \\
\hline Mean & $9.189 \mathrm{~B}$ & $10.67 \mathrm{AB}$ & $11 . .32 \mathrm{~A}$ & & $1.074 \mathrm{~A}$ & $0.781 \mathrm{~A}$ & $0.643 \mathrm{~B}$ & \\
\hline
\end{tabular}

$\mathrm{I}_{1}$-Two days interval $\mathrm{I}_{2}$ - three days interval $\mathrm{I}_{3}$ - four days interval

1- Control P.S.- Potassium silicate S.S.- Sodium silicate C.C.- Calcium carbonate M.C.--Magnesium carbonate A.S - aluminum silicate (Kaolin)Values within the column or rows followed by the same capital or small letter /s do not significantly differ from each other according to Duncan 's multiple range test at 5 $\%$ level

\section{9-Total titratable acidity}

In respect to the effect of irrigation intervals, data in Table (5) show that the highest value of acidity of strawberry fruits were recorded under sufficient water and there were no significant differences in acidity between two and three days irrigation intervals .While, under irrigation every four days showed the lowest values of acidity in the two tested seasons. The current results are in contrast to those of Mannini and
Gallina (1994) and disagreement with Liu et. al ., (2001) on strawberry

As regard to foliar application of antitranspirants effect on the acidity, results in Table (5) clearly show that spraying of any antitranspirants had no significant differences among them and the control in the first season. However in the second season the highest value of acidity was obtained from the control fruits followed by sodium silicate, calcium carbonate and kaolin . 
Data in Table (5) reveal that the highest fruit acidity was obtained from the interaction between irrigation each two days and control in the two tested seasons. However, foliar spraying with any of antitranspirants and irrigation each four days produced the lowest values of total acidity. Generally, foliar spraying with antitranspirants under low water requirements had the lowest values of fruit acidity in both seasons

\section{0-Ascorbic acid content.}

Data in Table (6) clearly indicate that the highest value of ascorbic acid content were detected at the two and three days irrigation intervals while the lowest value was obtained under insufficient water condition (four days) in both tested seasons. Our results are in harmony with El-sayed (2015) and disagreement with Klar et al., (1990) on strawberry. As for application of antitranspirants effect, data in Table (6) show that foliar spraying with sodium silicate and magnesium carbonate had the highest values in both tested seasons and there were no significant differences among the rest of antitranspirants and untreated plants. Concerning the interactions effect, results in Table (6) indicate that the highest value of ascorbic acid content were detected from spraying each of sodium silicate and magnesium carbonate with plants irrigated each two or three days.

Table (6): Effect of Irrigation intervals, some antitranspirants and their interactions on ascorbic acid and chlorophyll content during the two growing seasons of 2013/2014 and 2014/2015.

\begin{tabular}{|c|c|c|c|c|c|c|c|c|}
\hline \multirow{3}{*}{$\begin{array}{l}\text { Character } \\
\text { Treatments }\end{array}$} & \multicolumn{4}{|c|}{ Vitamin c (mg/100g) } & \multicolumn{4}{|c|}{ Total Chlorophyll (spad) } \\
\hline & \multicolumn{8}{|c|}{ Irrigation intervals } \\
\hline & $\mathrm{I}_{1}$ & $\mathrm{I}_{2}$ & $\mathrm{I}_{3}$ & Mean & $\mathrm{I}_{1}$ & $\mathrm{I}_{2}$ & $I_{3}$ & Mean \\
\hline \multicolumn{9}{|c|}{ 2013-2014 } \\
\hline Control & $42.40 \mathrm{~b}$ & 45.76defg & $37.47 \mathrm{i}$ & $42.40 \mathrm{~B}$ & $46.12 \mathrm{c}$ & $47.20 \mathrm{efg}$ & $42.67 \mathrm{~h}$ & $46.12 \mathrm{C}$ \\
\hline P.S. & $48.79 a b$ & $53.18 \mathrm{bc}$ & 44.46 efgh & $48.79 \mathrm{AB}$ & $54.71 \mathrm{a}$ & $56.50 \mathrm{ab}$ & $49.23 \mathrm{e}$ & $54.71 \mathrm{~A}$ \\
\hline S.S. & $53.14 \mathrm{a}$ & $61.68 \mathrm{a}$ & $39.06 \mathrm{hi}$ & $53.14 \mathrm{~A}$ & $53.27 \mathrm{ab}$ & $55.10 \mathrm{~cd}$ & 48.63 ef & $53.27 \mathrm{AB}$ \\
\hline C.C. & $47.93 \mathrm{ab}$ & $51.51 \mathrm{~cd}$ & 42.26 ghi & $47.93 \mathrm{AB}$ & $44.88 \mathrm{c}$ & $46.53 \mathrm{fg}$ & $45.13 \mathrm{~g}$ & $44.88 \mathrm{C}$ \\
\hline M.C. & $55.59 \mathrm{a}$ & $63.13 \mathrm{a}$ & 44.62 efgh & $55.59 \mathrm{~A}$ & $51.87 b$ & $53.77 \mathrm{~d}$ & $45.40 \mathrm{~g}$ & $51.87 \mathrm{~B}$ \\
\hline A S. & $49.35 a b$ & 48.13 cdef & $50.57 \mathrm{~cd}$ & $49.35 \mathrm{AB}$ & $54.00 \mathrm{ab}$ & $55.03 \mathrm{~cd}$ & 48.27 ef & $54.00 \mathrm{AB}$ \\
\hline Mean & $51.63 \mathrm{~A}$ & $53.90 \mathrm{~A}$ & $43.07 \mathrm{~B}$ & & $53.73 \mathrm{~A}$ & $52.50 \mathrm{~A}$ & $46.19 \mathrm{~B}$ & \\
\hline \multicolumn{9}{|c|}{$2014-2015$} \\
\hline Control & $49.68 \mathrm{bc}$ & 50.09 efg & $49.52 \mathrm{fg}$ & $49.68 \mathrm{BC}$ & $44.56 \mathrm{c}$ & 45.67 efg & $43.40 \mathrm{ghi}$ & $44.56 \mathrm{C}$ \\
\hline P.S. & $53.25 b$ & $57.55 \mathrm{bc}$ & 49.84 efg & $53.25 \mathrm{~B}$ & $52.37 \mathrm{a}$ & $53.80 \mathrm{~cd}$ & 46.77ef & $52.37 \mathrm{~A}$ \\
\hline S.S. & $63.34 \mathrm{a}$ & $68.25 \mathrm{a}$ & 54.56 cde & $63.34 \mathrm{~A}$ & $51.91 \mathrm{a}$ & $54.47 \mathrm{bc}$ & $47.20 \mathrm{e}$ & $51.91 \mathrm{~A}$ \\
\hline C.C. & $48.61 \mathrm{c}$ & $42.08 \mathrm{~h}$ & $48.52 \mathrm{fg}$ & $48.61 \mathrm{C}$ & $42.98 \mathrm{c}$ & 42.83 hij & $41.37 \mathrm{ij}$ & $42.98 \mathrm{C}$ \\
\hline M.C. & $60.86 \mathrm{a}$ & $71.61 \mathrm{a}$ & $49.99 \mathrm{efg}$ & $60.86 \mathrm{~A}$ & $49.18 b$ & $52.00 \mathrm{~d}$ & 45.67 efg & $49.18 B$ \\
\hline A.S. & 52.27 bc & 53.51cdef & $47.32 \mathrm{~g}$ & $52.27 \mathrm{BC}$ & $52.8 \mathrm{a}$ & $54.07 \mathrm{~cd}$ & $46.53 \mathrm{ef}$ & $52.8 \mathrm{~A}$ \\
\hline Mean & $56.87 \mathrm{~A}$ & $57.18 \mathrm{~A}$ & $49.9 B$ & & $51.81 \mathrm{~A}$ & $50.75 \mathrm{~A}$ & $44.34 \mathrm{~B}$ & \\
\hline
\end{tabular}

$\mathrm{I}_{1}$-Two days interval $\mathrm{I}_{2}$ - three days interval $\mathrm{I}_{3}$ - four days interval

1- Control P.S.- Potassium silicate S.S.- Sodium silicate C.C.- Calcium carbonate M.C.--Magnesium carbonate A.S - aluminum silicate (Kaolin)Values within the column or rows followed by the same capital or small letter/s do not significantly differ from each other according to Duncan 's multiple range test at 5 $\%$ level 


\section{1-Total chlorophyll content.}

It is clear from results in Table (6) that strawberry plants irrigated every two or three days showed significant higher values of chlorophyll content as compared with plants irrigated every four days interval.Decreasing in chlorophyll content under drought condition was observed by Nikolaeva et. al., (2010) and (El- Sayed et.al ., and Arash et. al., (2015)

Regarding antitranspirants materials effect ,data in Table (6) indicate that spraying of potassium silicate, sodium silicate and kaolin gave the highest values of chlorophyll content followed by magnesium carbonate while spraying of calcium carbonate and untreated plants gave the lowest values of chlorophyll in both tested seasons. Obtained results on kaolin are agreeable with those reported by Khaleghi et. al., (2015) on olive trees and Jifon and Syvertsen (2003) on grapefruit trees

Results in Table (6) show that the best treatment combination among foliar spraying of kaolin under two days irrigation intervals in both seasons followed by potassium and sodium silicate. On the other hand, potassium and sodium silicate under three days irrigation interval were the best treatments in the tested seasons. Under water stress with spraying of potassium, sodium silicate and kaolin were better than the rest of antitranspirants and untreated plants. Our results on kaolin are in harmony with findings of those obtained from Wang and Galletta (1998) on strawberry and Ezzat et. al., (2009) on potato.

\section{2-Early yield}

Results in Table (7) clearly indicate that the highest early yield were obtained from the three days irrigation interval followed by the check interval (two days) and non significant differences were detected between the early yield produced from the four days interval and check interval in the first season. However, in second season two and the three days intervals gave the highest early yield .While, under four days interval condition the plants produced the lowest value of early yield. Similar results were obtained with El - Sayed, et.al.,(2015) on strawberry .

Data in Table (7) reveal that there were significant differences among the treated treatments and the highest early yield was resulted from potassium silicate, calcium carbonate, magnesium carbonate and kaolin treatments. While in the second season the highest early yield were obtained from both of magnesium carbonate and kaolin treatments and there were no significant difference between kaolin and calcium carbonate treatments followed by, potassium silicate and sodium silicate treatments. On the other hand, the plants were not treated with any antitranspirants produced the lowest early yield.

Data tabulated in Table (7) indicate that the highest early yield /plant and /fed were obtained from foliar spray of potassium silicate treatment with plants irrigated every three days in the first season only and no significant differences were detected between it and spraying of magnesium carbonate or kaolin .However, kaolin had the superior early yield in the second season with plants irrigated every three days .In general, in both seasons application of antitranspirants had significant effect on early yield compared to non treated plants with plants irrigated every three days our finding in agreement with Caulet et. al.,(2014) .

\section{3-Total yield .}

Data listed in Table (8) show that highly significant differences among the three irrigation intervals on the total yield in both seasons and the highest value was obtained 
from irrigated plants every two days followed by three days interval. On the other hand, irrigation every four days produced the lowest value of total yield. This results are in agreement with Klar, et. al., (1990), Bordonaba and Terry (2009), Li et al. (2010) and El - Sayed et.al., (2015) on strawberry .

Table (7): Effect of Irrigation intervals, some antitranspirants and their interactions on early yield / plant and /fed. during the two growing seasons of 2013/2014 and 2014/2015

\begin{tabular}{|c|c|c|c|c|c|c|c|c|}
\hline \multirow{3}{*}{$\begin{array}{l}\text { Gharacter } \\
\text { Treatments }\end{array}$} & \multicolumn{4}{|c|}{$\begin{array}{l}\text { Early yield } \\
\text { (g/plant) }\end{array}$} & \multicolumn{4}{|c|}{$\begin{array}{l}\text { Early yield } \\
\text { (ton/fed) }\end{array}$} \\
\hline & \multicolumn{8}{|c|}{ Irrigation intervals } \\
\hline & $\mathrm{I}_{1}$ & $\mathrm{I}_{2}$ & $I_{3}$ & Mean & $I_{1}$ & $\mathrm{I}_{2}$ & $I_{3}$ & Mean \\
\hline & \multicolumn{8}{|c|}{ 2013-2014 } \\
\hline Control & 80.89 e & $51.29 \mathrm{f}$ & $35.9 \mathrm{~g}$ & $56.03 \mathrm{C}$ & $3.237 \mathrm{e}$ & $1.870 \mathrm{f}$ & $1.343 \mathrm{~g}$ & $2.180 \mathrm{C}$ \\
\hline P.S. & $96.61 \mathrm{abcd}$ & $105.4 \mathrm{a}$ & $98.83 \mathrm{abc}$ & $100.3 \mathrm{~A}$ & 3.863abcd & $4.217 \mathrm{a}$ & $3.963 a b c$ & $4.010 \mathrm{~A}$ \\
\hline S.S. & 85.49 de & $103.1 \mathrm{abc}$ & 92.05 cde & 93.54 B & $3.420 \mathrm{de}$ & $4.121 a b c$ & 3.680 cde & $3.740 \mathrm{~B}$ \\
\hline C.C. & $100.7 \mathrm{abc}$ & 103.9abc & $98.39 \mathrm{abc}$ & $101.0 \mathrm{~A}$ & $4.027 \mathrm{abc}$ & 4.160abc & $3.937 \mathrm{abc}$ & $4.041 \mathrm{~A}$ \\
\hline M.C. & $100.9 \mathrm{abc}$ & $105.0 \mathrm{ab}$ & $98.52 \mathrm{abc}$ & $101.5 \mathrm{~A}$ & $4.037 \mathrm{abc}$ & $4.083 a b$ & $3.940 a b c$ & $4.020 \mathrm{~A}$ \\
\hline A.S. & $97.96 \mathrm{abcd}$ & $104.9 a b$ & $92.51 \mathrm{bcde}$ & $98.45 \mathrm{~A}$ & 3.917abcd & $4.170 a b$ & 3.697bcde & $3.928 \mathrm{~A}$ \\
\hline \multirow[t]{2}{*}{ Mean } & $93.76 \mathrm{AB}$ & $95.60 \mathrm{~A}$ & 86.04 B & & $3.750 \mathrm{AB}$ & $3.824 \mathrm{~A}$ & 3.442 B & \\
\hline & \multicolumn{8}{|c|}{ 2014-2015 } \\
\hline Control & $78.00 \mathrm{e}$ & $47.57 \mathrm{f}$ & $26.90 \mathrm{~g}$ & $50.82 \mathrm{D}$ & $3.120 \mathrm{e}$ & $1.903 f$ & $1.077 \mathrm{~g}$ & $2.033 \mathrm{D}$ \\
\hline P.S. & 82.17 bcde & $95.20 \mathrm{abc}$ & $81.37 \mathrm{cde}$ & $86.24 \mathrm{C}$ & 3.290 bcde & 3.807abc & $3.253 \mathrm{cde}$ & $3.450 \mathrm{C}$ \\
\hline S.S. & $78.13 \mathrm{de}$ & $93.77 \mathrm{abc}$ & 84.97 abcde & $85.62 \mathrm{C}$ & $3.127 \mathrm{de}$ & $3.750 a b c$ & 3.397abcde & $3.424 \mathrm{C}$ \\
\hline C.C. & 84.07abcde & $94.00 \mathrm{abc}$ & $92.93 a b c$ & 90.33 B & 3.363abcde & $3.760 a b c$ & $3.713 a b c$ & 3.612 B \\
\hline M.C. & 91.97abcde & $95.73 a b$ & $92.43 \mathrm{abcd}$ & $93.38 \mathrm{~A}$ & 3.677abcde & $3.830 a b$ & $3.697 \mathrm{abcd}$ & $3.734 \mathrm{~A}$ \\
\hline A.S. & $92.97 \mathrm{abc}$ & $97.23 \mathrm{a}$ & 88.73 abcde & $92.98 \mathrm{AB}$ & $3.717 \mathrm{abc}$ & $3.877 \mathrm{a}$ & 3.547abcde & $3.713 \mathrm{AB}$ \\
\hline Mean & $84.55 \mathrm{~A}$ & $87.25 \mathrm{~A}$ & 77.89 B & & $3.380 \mathrm{~A}$ & $3.488 \mathrm{~A}$ & $3.115 \mathrm{~B}$ & \\
\hline
\end{tabular}

$\mathrm{I}_{1}$-Two days interval $\mathrm{I}_{2}$ - three days interval $\mathrm{I}_{3}$ - four days interval

1- Control P.S.- Potassium silicate S.S.- Sodium silicate C.C.- Calcium carbonate M.C.--Magnesium carbonate A.S - aluminum silicate (Kaolin)Values within the column or rows followed by the same capital or small letter /s do not significantly differ from each other according to Duncan 's multiple range test at 5 $\%$ level 
Table (8): Effect of Irrigation intervals, some antitranspirants and their interactions on total yield / plant and /fed. during the two growing seasons of $2013 / 2014$ and 2014/2015.

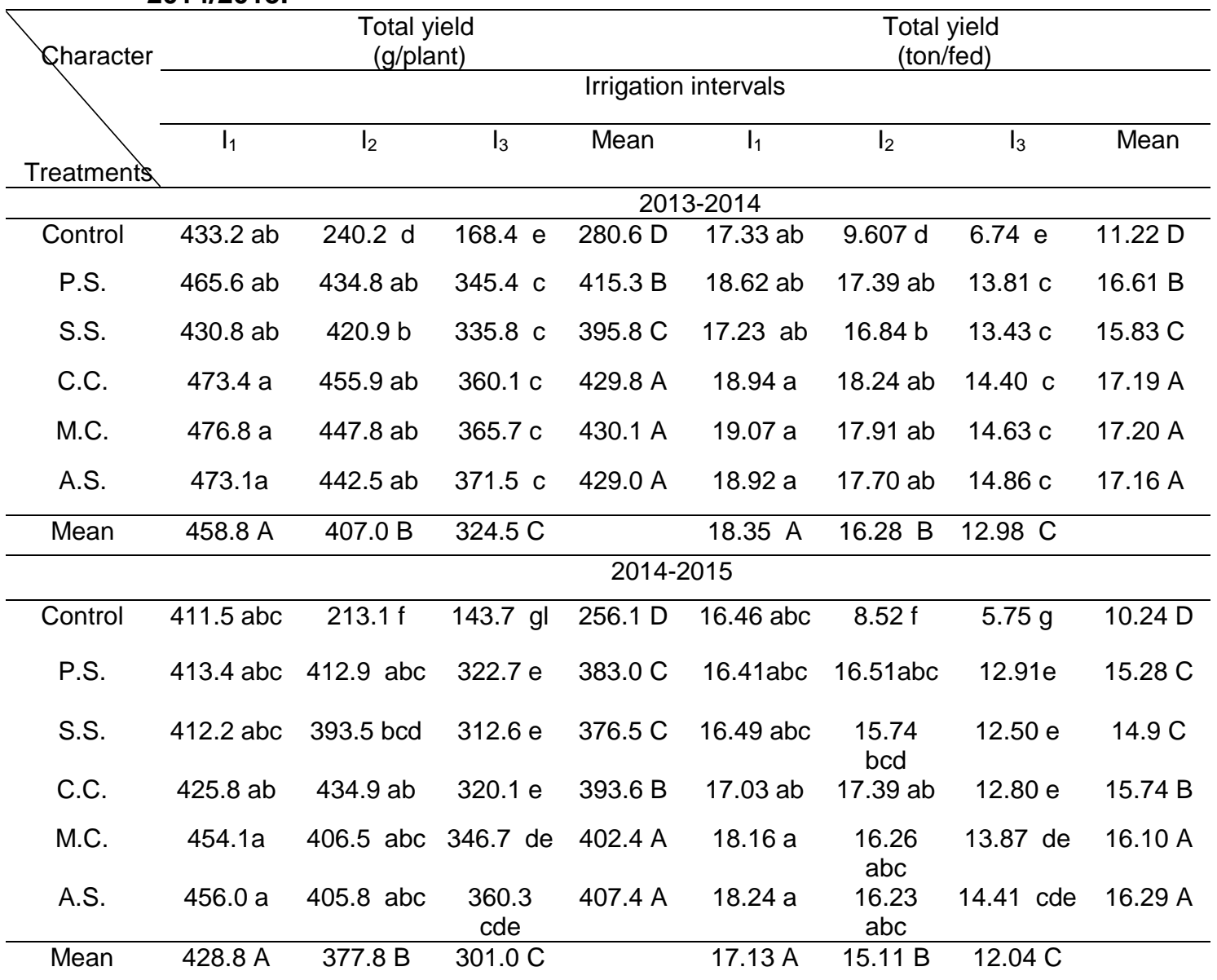

$\mathrm{I}_{1}$-Two days interval $\mathrm{I}_{2}$ - three days interval $\mathrm{I}_{3}$ - four days interval

1- Control P.S.- Potassium silicate S.S.- Sodium silicate C.C.- Calcium carbonate M.C.--Magnesium carbonate A.S - aluminum silicate (Kaolin)Values within the column or rows followed by the same capital or small letter /s do not significantly differ from each other according to Duncan 's multiple range test at $5 \%$ level

Concerning the effect of antitranspirants, results in Table (8) show that the highest total yields were produced from treated plants with calcium carbonate, magnesium carbonate and kaolin followed by potassium silicate, sodium silicate and untreated plants in the first season, respectively. In the second season, treated plants with each of magnesium carbonate and kaolin produced the highest values followed by calcium carbonate .Moreover, there were no significant differences between potassium silicate and sodium silicate but both of them were higher than untreated plants. Similar results were obtained with on strawberry and Ibrahim and Selim (2010) on squash.

In respect to the effect of interactions, data in Table (8) show that the best combinations that gave the highest values of total yield appeared to be that involving calcium carbonate, magnesium carbonate and kaolin with plants irrigated each two days without any significant differences among all antitranspirants and untreated plants. In addition, there were no significant differences noted in total yield between two and three days irrigation intervals by using all antitranspirants materials except sodium 
silicate treatment in the two tested seasons. Under drought stress condition (each four days) all antitranspirants gave higher values of total yield than the untreated plants especially kaolin treatment produced the highest total yield.These results are in harmony with Santos et. al ., (2012) Johnson and Simpson, ( 2014) and Deaquiz et. al., (2014) on strawberry.

\section{REFERENCES}

Akhtar, I. and A. Rab (2015). Effect of irrigation intervals on the quality and storage performance of strawberry fruit. Journal of Animal and Plant Sciences. 25 (3): 669-678.

Arash, N., G. Faruq and K. Rashid (2015). Influence of drought stress on leaf traits of different strawberry (Fragaria $x$ ananassa L.) varieties in natural environment. Soil Science and Plant Analysis; 46 (10):1249-1262.

A.O.A.C (2000).Official Methods of Analysis. 13 th Ed. Association of Official Chemists Washington DC. USA.

Bafeel, S. O. and A. E. Moftah (2008). Physiological response of eggplants grown under different irrigation regimes to antitransplant treatments. Saudi J. of Biolo. Sciences, 15 (2): 259-267.

Bielinski, M. S., P. Teresa, S. Donoso and A.J. Whidden (2012). Reducing Sprinkler Irrigation Volumes for Strawberry Transplant Establishment in Florida Hort technology 4 : 224-227.

Bordonaba, J. G. and L.A. Terry (2009). Differential effect of water deficit irrigation on fruit quality of five june-bearing strawberry cultivars. Acta Horticulturae;. (838):187-192.

Caulet, R. P., G. Gradinariu, D lurea and A. Morariu (2014). Influence of furostanol glycosides treatments on strawberry (Fragaria $x$ ananassa Duch.) growth and photosynthetic characteristics under drought condition. Scientia Horticulturae. 169: 179-188.

Deaquiz, Y. A., A. Herrera, J. G. Pinzon and L. P. Gomez (2014). Effect of different irrigation water levels on the production and quality of the strawberry (Fragaria sp.). [Spanish] Revista Colombiana de Ciencias Horticolas;. 8(2):192-205.

El-Sayed, E., G.S.A. Eisa and I.Z.A. El Shimi (2015). Effect of irrigation water quality and treating with diatomite on productivity, water use efficiency and anatomical characters strawberry plants grown in sandy soil . Zagazig J. Agric . Res., Vol . 42 N O. (3) 457-473.

El -Zohiri, S.S. and A.M.H. Abd-Aal (2014). Improve the adverse impacts of water stress on growth,yield and its quality of taro plants by using glycinebetaine , $\mathrm{MgCO}_{3}$ and defoliation under delta conditions. Middle East Journal of Agriculture Research 3 (4) :799-814

Ezzat, A. S., U.M. Saif Eldeen and A.M. Abd El-Hameed (2009). Effect of irrigation water quantity antitranspirants and humic acid on growth, yield nutrients content and water use efficiency of potato (Solanum tuberosum J. Agric.Sci. Mansoura Univ., (12) : 11585-11603 .

Francisco, M. D. A. and J.S. Rubio (2009). Effects of Antitranspirants Spray and Potassium: Calcium: Magnesium Ratio on Photosynthesis, Nutrient and Water Uptake, Growth, and Yield of Sweet Pepper. Journal of Plant Nutrition $\underline{32}$ (1) : 97-111.

Gawish, A. R. and M.A Fattahallah. (1997).Modification of irrigation requirements of taro (Colocasia esculenta L.) through the application of antitranspirants. Minufiya J. Agric. Res. 22 (5):1353-1387.

Gerhmann, H. (1985). Growth, yield and fruit quality of strawberries as affected by water stress Acta Hort. 171: 463.

Grant, O. M., M. J. Davies, A.W. Johnson and D. W. Simpson (2012). Physiological and growth responses to water deficits in cultivated strawberry (Fragaria $x$ ananasa L.) and in one of its progenitors, Fragaria chiloensis. Environmental and Experimental Botany; 83:23-32.

Ibrahim, E.A. and E. M. Selim (2010). Effect of irrigation intervals and antitranspirants (kaolin) on summer squash (Cucurbita pepo L.) growth, yield, quality and 
economics. J. Soil Sci. and Agric. Engineering, Mansoura Univ., 1 (8): 883894.

Jifon, J.L. and J.P. Syvertsen (2003). Kaolin particle film applications can increase photosynthesis and water use efficiency of "Ruby Red" grapefruit leaves. J. Am. Soc. Hort. Sci. 128, 107-112.

Johnson, A.W. and D. W. Simpson (2014). The effect of deficit irrigation on the flowering behavior of two day-neutral and one ever bearing strawberry cultivar. Acta Horticulturae; (1049):435-438.

khaleghi, E., K. Arzani, N. Moallemi and M. Barzegar (2015). The efficacy of kaolin particle film on oil quality indices of olive trees (Olea europaeaL.) cv 'Zard' grown under warm and semi-arid region of Iran. Food Chem.166: 35-41.

Khayyat, M., S. Rajaee, A. Sajjadinia, S. Eshghi and E. Tafazoli (2009). Calcium effects on changes in chlorophyll contents, dry weight and micronutrients of strawberry (Fragaria $x$ ananassa Duch.) plants under salt-stress conditions.Fruits (Paris); 64(1):53-59.

Klamkowski, K. and W. Treder (2008). Response to drought stress of three strawberry cultivars grown under greenhouse conditions. Journal of Fruit and Ornamental Plant Research 16: 179-88.

Klar, A. E., S. Campos and A. Cataneo (1990). Water stress in strawberry plants (Fragaria spp.). I. Production, vitamin C, protein and water contents of the fruits. Cientifica (Jaboticabal); 18(2):45-61.

Li, H., T., R. J. Gordon, S. K. Asiedu and K. Hu. (2010). Strawberry plant fruiting efficiency and its correlation with solar irradiance, temperature, and reflectance water index variation. Environmental and Experimental Botany 68: 165-74.

Liu , M., K. Takayuki, T. Munehiro and C. Hang (2001). Effect of Soil Moisture on Plant Growth and Fruit Properties of Strawberry. Acta Horticulturae. 28 (4) : 307-311.

Nikolaeva, M.K., S.N. Maevskaya, A.G. Shugaev and N.G. Bukhov (2010). Effect of drought on chlorophyll content and antioxidant enzyme activities in leaves of three wheat cultivars varying in productivity. Russian Journal of Plant Physiology 57:87-95

Mannini, P. and D. Gallina (1994). Yield and quality response of strawberries to irrigation. Rivista di Frutticolturae di Ortofloricoltura;. $56 \quad$ (4) : 69-73. Agricultura Técnica en México Vol. 35

Modise, D. M. (2013). Growth and expansion of strawberry fruit (Fragaria $x$ ananassa Duch.) under water stress conditions. African Journal of Agricultural Research; (2013). 8(46):5703-5711.

Motamedi, S., M. Jafarpour and J. Shams (2013). Evaluation of nutrition on flower number and yield of strawberry in greenhouse. International Journal of Agriculture and Crop Sciences 5(18):2091-2095.

Rosati, A. (2007). Physioligical effects of kaolin particle film technology: A Review. Functional plant science and biotechnology (1) 100-105.

Shinohara, T. and D.I. Leskovar (2014). Effects of ABA, anti-transparent, heat and drought stress on plant growth, physiology and water status of artichoke transplants. Sci. Hortic. 165: 225-234.

Snedecor, G.W. and W.G. Cochran (1982). Statistical Methods $7^{\text {th }}$ Ed. $2^{\text {nd }}$ printing , Lowa State . Univ. Press, Amer., USA, pp507.

Terry, L.A., G. A. Chope and J. G. Bordonaba (2009). Effect of water deficit irrigation on strawberry (Fragaria $x$ ananassa) fruit quality. Acta Horticulturae;. (842):839-842.

Wang, S. Y. and G. J. Galletta (1998). Foliar application of potassium silicate induces metabolic changes in strawberry plants. Journal of Plant Nutrition. 21(1):157-167.

Vito, C., B. Pace and R. Lbrizio (2009). Kaolin- based particle film technology affects tomato physiology, yield and quality . Environmental and experimental botany. 66 (2) : 279- 288. 
تأثير فترات الري و مضادات النتح على نمو ومحصول وجودة الفراولة تحت نظام الري بالتتقيط 1-النمو الخضري والصفات الطبيعية ؛الكيماوية للثمار والمحصول المبكر والكلى للنبات

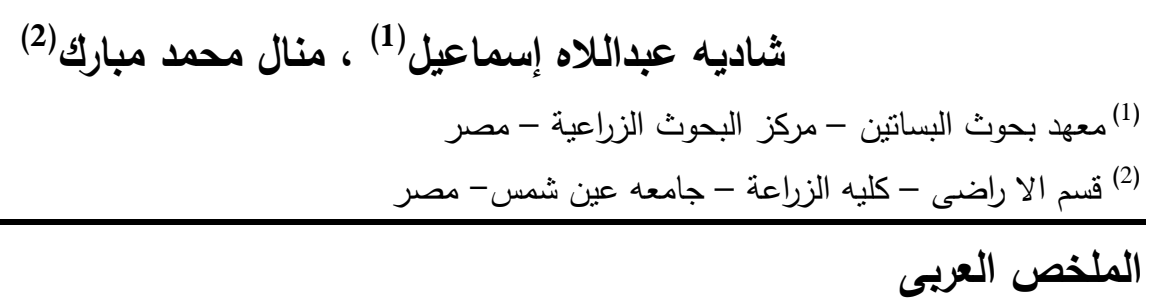

أجريت هذه الدراسة خلال موسمي 2013-2014 ، 2014-2015 بالمزرعة البحثية محطة بحوث البساتين

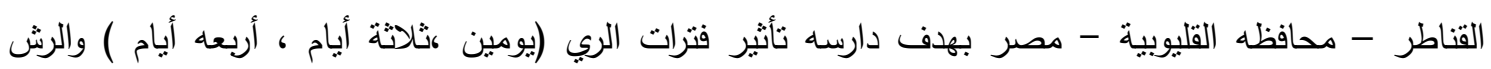

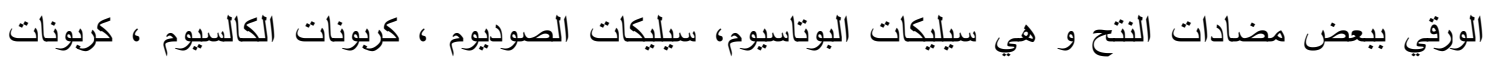

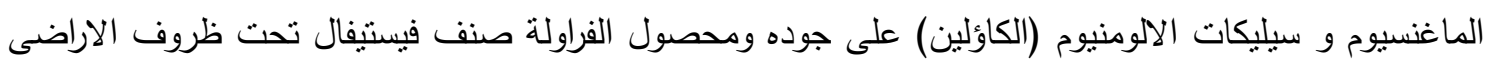

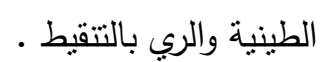



1- لم يكن هناك فرق معنوي بين الري كل يومين وثلاثة أيام في عدد الأوراق مع زيادة عدد الأوراق للنبات بالرش


الكاؤلين وسيليكات البوتاسيوم وتباعد فترة الري إلى ثناث أيام إلى زيادة معنوية في كلا من عدد الأوراق

$$
\text { ومساحه الورقة . }
$$

2- تأثز ارتفاع النبات بزيادة تباعد فترات الري وكان أعلى ارتفاع نتيجة التفاعل بين الري كل يومين مع الرش بأي



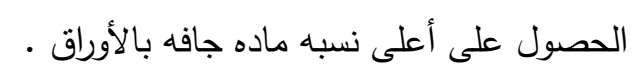
3- تأثز عدد وطول الجذور معنويا بتباعد فترات الري وأدى التفاعل بين الري كل ثلاثة أيام و الرش الكاؤلين أو

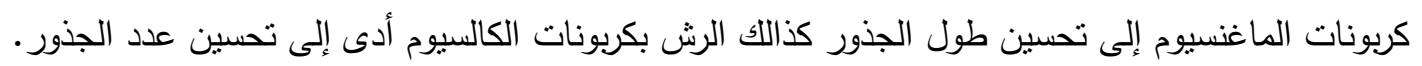
4- زيادة تباعد فترات الري أدى إلى انخفاض معنوي في قطر التاج إلا إن كل معاملات الرش بمضادادات النتح

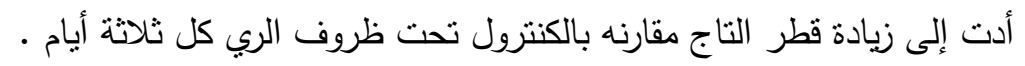



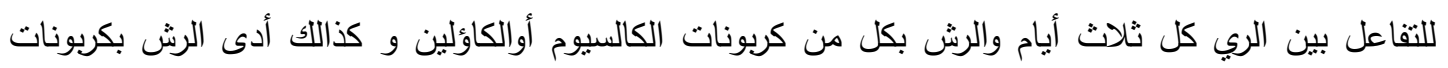

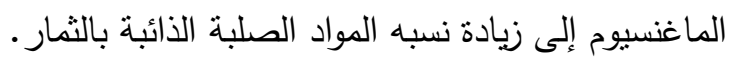

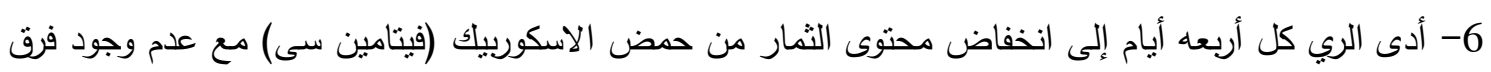
معنوي بين الري كل ثلاث أو أربعه أيام مع الرش بأي من سيليكات البوتاسيوم أو كربونات الماغنسيوم. 
7- كان هناك انخفاض في محتوى الكلوروفيل بالأوراق مع تباعد فترات الري وأدى التفاعل بين الري كل ثلاثة أيام

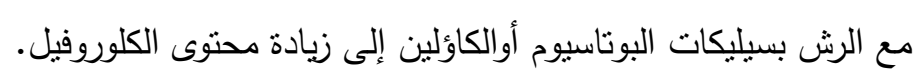

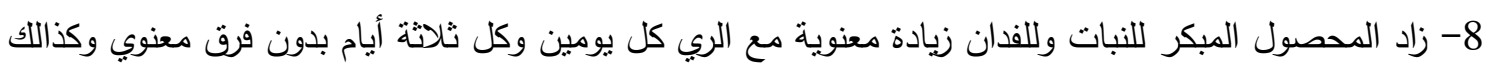

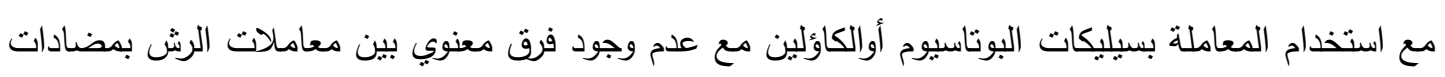
النتح مقارنه بالكنترول.

9- تأثر المحصول الكلى للنبات وللفدان معنويا بتباعد فترات الري وأدى التفاعل بين الرى كل ثناثة أيام والرش

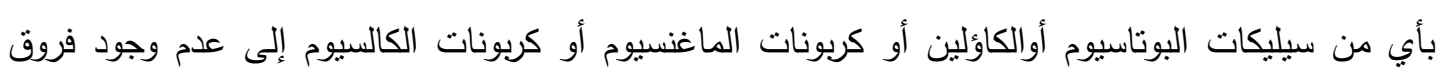
معنوية مع الري كل يومين. ولذا يمكن أن توصى الدراسة برى نبات الفراولة تحت ظروف الاراضى الطينية والري بالتتقيط كل ثلاثة أيام

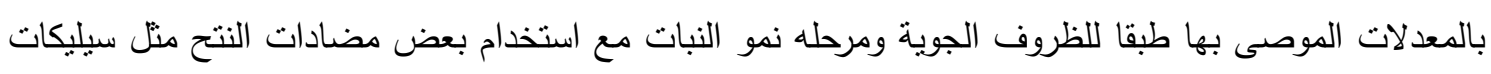

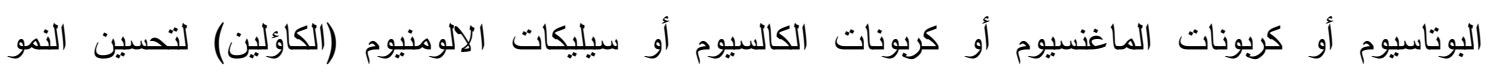

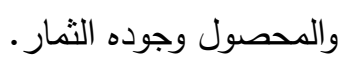

